\title{
Impact Of Lithology and Regional Climate Variability on Spring Characteristics Between Uttarkashi and Harsil, Garhwal Himalaya, India
}

\author{
Amit Kumar $^{1 *} \cdot$ Nagendra Prasad Naithani $^{1}$ \\ ${ }^{1}$ Department of Geology, H.N.B. Garhwal University Srinagar, Uttarakhand \\ *Corresponding Author Email id: kandwalamitkandwal25@gmail.com
}

Received: 15.02.2021; Revised: 23.03.2021; Accepted: 30.03.2021

(C)Society for Himalayan Action Research and Development

\begin{abstract}
Spring characteristics are dependent upon the nature of lithology and precipitation in the region. The area is divided into two zones based on their lithological characters, viz: lesser Himalayan zone and Central Crystalline Zone for the hydrogeological study. Forty-five springs and four hot springs under different lithological controls were studied to understand spring discharges' response to regional climate variability. Four types of springs, fracture jointrelated springs, colluvial springs, Karst and seepages, and contact springs identified, which emanates from two geohydrological zones with in the study area. Colluvial springs yield are higher in comparison to the fracture jointrelated springs. The study revealed that the regional climatic pattern and precipitation pattern has a direct impact on spring hydrology.
\end{abstract}

Keywords: Uttarkashi $\bullet$ Discharge $\bullet$ Springs $\bullet$ Hot springs $\bullet$ Lithology $\bullet$ Precipitation

\section{Introduction}

The availability of water is an essential component for the development of agriculture and society. Springs are drying up or their discharge is reducing throughout the Himalayas (NITI Aayog, 2018, Bartarya, 1995). Increasing temperature, irregular precipitations, environment shifts impact distribution, consistency and quantity in Uttarakhand, snowmelt, stream flow and groundwater reserves. Global warming is one of the major climate change that has a direct effect on water resources (Panwar, 2020). The average global air temperature is expected to rise by $1.2{ }^{\circ} \mathrm{C}$ from the present time to the year 2050 (Yang, 1999, Jeelani, 2008), this leads to the gradual retirement of the ice cover, which is the biggest threat to drinking water sources. Spring hydrology studied in the Himalayan region by several researchers, Valdiya and Bartarya (1989), Tiwari (2008), Agarwal et al. (2012), Grover (2015), Jeelani et al. (2018). Gupta and Deshpande (2004), stated that the amount of water in many parts of India has been declining rapidly over the past two decades due to a rise in extraction, with climate change impacting water resources. A study by the "International Association of Hydrological Sciences" (IAHS) reported that the Himalayan glaciers are shrinking faster than any other region of the planet and if the same trend continues, they are likely to disappear by 2030 . The approximate average retreat rates for the Gangotri and Dokrani glaciers (Garhwal Himalaya) were

24.6 m.year -1 between 1953 and 1976 (Hasnain 1999) and 15.1 m.year -1 between 1962 and 1995 (Gergan et al. 1999). Spring water discharge has been affected by both rainfall and recharge area characteristics (Rai et al. (1998), Negi and Joshi (1996) Bisht and Srivastava (1995), Sahin and Hall (1996), Negi and Joshi (2004). Asoka et al. (2017) reported that storage of groundwater in Northern India decreased by $2 \mathrm{~cm}$ year- 1 due to climatic change and excessive groundwater pumping.

The drying up of particular seasonal springs and the retreating spring discharges have attracted scientists to determine the effect of regional climate change on discharge of springs under various lithological conditions. The present study 
aimed to better understand these springs' essential characteristics by undertaking an extensive field survey and springs response to regional climate variability and lithological controls on the aquifer system's water yield in the study area. Geology and hydrogeology of the region Based on rock type, the hydrogeology of the area can be explained in the following parts.

\section{Lesser Himalaya Zone}

The Lesser Himalayan part of the study area consists of the Garhwal group of rocks, further divided into different formations such as Uttarkashi limestone, Sartali slates, and Netala quartzite, Gamri quartzite, schistose quartzite, and epidiorite. It is generally believed that the groundwater in quartzites is scarce and undependable. The quartzite extending from Gangori to Hinna along the right bank of the Bhagirathi river are fractured, faulted, and fissured to such an extent that they form substantial underground reservoirs. Uttarkashi Limestone is well exposed in the Uttarkashi window in which large solution openings, which are produced when part of the rock is dissolved by groundwater, are standard in carbonate rocks. Highly metamorphosed rocks are controlled by structural features such as joints, lineaments, fissures, and fractures, causing storage and transmission of large water quantities. Springs are originated along with geological structures such as faults, joints, and fractures. The high porosity and high permeability of alluvium are suitable for groundwater development in the study area.

\section{Central crystalline Zone}

The area above Main Central Thrust (MCT) is highly metamorphosed constituted of metasediments, metabasics, migmatites, and different types of highly graded gneisses and schists, Gupta, \& Dave (1982). Generally, unfractured metamorphic rock and igneous rock have porosities that are rarely larger than $2 \%$. In metamorphic rocks, pre-existing minerals start to recrystallize into new minerals; thus it develops Secondary porosity. The area is continuously facing high tectonic activity due to which rocks of the area showing fracturing, faulting, and dissolution, which creates secondary porosity for groundwater development. Springs are originated through the contacts and fractures of rocks. Gneisses in unweathered conditions have less porosity and cannot hold water; after natural processes, these rocks are fractured, providing interconnected fissures that allow percolation of surface water. Depending on the areal extent and depth of weathering, these layers constitute potential aquifers in regions of crystalline gneissic rocks.

\section{Methodology}

Forty-five freshwater springs and four hot water springs were identified during the field excursions were carried out between August 2016 to May 2018 to collect the discharge data of springs on the monthly-basis, geological, geomorphological, and hydrogeological information of the study area. Each spring's discharge is measured monthly with a measuring flask and stopwatch-precipitation data of previous years collected from the DM office, meteorological department, and internet source. GIS software used to prepare maps and hydrographs are prepared with the help of Origin software.



Figure 1: Location map of sampling sites in the study area

\section{Type of springs}

The springs of the area are classified based on lithological formations related to the opening of springs. Mainly four types of springs are dominant; fracture joint-related springs, colluvial springs, Karst and seepages, and contact springs (Table 1). 
Table:1 Summary of 1 springs dischargeunder different geological controls

\begin{tabular}{lllllll}
\hline S. & Spring detail & FJ joint & colluvial & Karst and \\
No & related sp. & sp & contact sp. & Hot sp. \\
& & & &
\end{tabular}

\begin{tabular}{|c|c|c|c|c|c|c|}
\hline 1 & No. of springs & 09 & 32 & 02 & 02 & 04 \\
\hline 2 & Average discharge & $16.66 \mathrm{~L} / \mathrm{m}$ & $21.80 \mathrm{~L} / \mathrm{m}$ & $61.92 \mathrm{~L} / \mathrm{m}$ & $5.72 \mathrm{~L} / \mathrm{m}$ & $21.71 \mathrm{~L} / \mathrm{m}$ \\
\hline 3 & $\begin{array}{l}\text { Discharge } \\
\text { springs }(\mathrm{L} / \mathrm{m})\end{array}$ & $0.6-355 \mathrm{~L} / \mathrm{m}$ & $\begin{array}{l}0.08-320 \\
\mathrm{~L} / \mathrm{m}\end{array}$ & $3.8-204 \mathrm{~L} / \mathrm{m}$ & $\begin{array}{l}1.1-12.2 \\
\mathrm{~L} / \mathrm{m}\end{array}$ & $3.8-98.2 \mathrm{~L} / \mathrm{m}$ \\
\hline
\end{tabular}

Fracture joint-related springs originate from fractures or joints within the metamorphic rocks of the study area. These springs are generally evolving either along the hill slope or the riverbed (Bartarya, 1995). Colluvial springs and seepage types are associated with debris cover and old landslide materials in the Bhagirathi valley and present at Sukki, Sunagarh, Bhukki, Aungi, Heena, Mandon, and Laksheshwar in which springs are originating from the soil and colluvial materials. Contact springs emanate from the contact of two different lithologies, i.e., Gneisses and Migmatites at Sukki, Calc Schist Marble, and Migmatites at Gangnani. Karst Springwater emanates through cavities and channels in carbonatic rocks, i.e., dolomites and limestone, at Netala 2 and Bonga 1.

\section{Spring discharge}

Discharge measurements of all the Forty-five springs and four hot water springs were carried out from August 2016 to May 2018 monthly (Table 2). The amount of water discharged by the spring varies with time and depends on both recharge of the aquifer and hydrological properties of the aquifer, such as porosity, permeability, hydraulic conductivity, etc., of the aquifer.

Discharge of springs shows the fluctuation in water level during a different season and direct relationship with precipitation and seasonal climatic pattern of the area.

Discharge reaches highest during monsoon season, Bonga-2 (355 L/m), Post monsoon period shows a decrease in discharge (Fig.no.2, D, (SP45)). Springs related to secondary permeability show an observable response to rainfall variation in the area. Flowing rainwater starts percolating down through the weathered mantle recharging groundwater, augmenting the discharge of springs/seepages. The water table decrease occurs through a high discharge rate, reduces its gradients, and detracts the pore pressure.

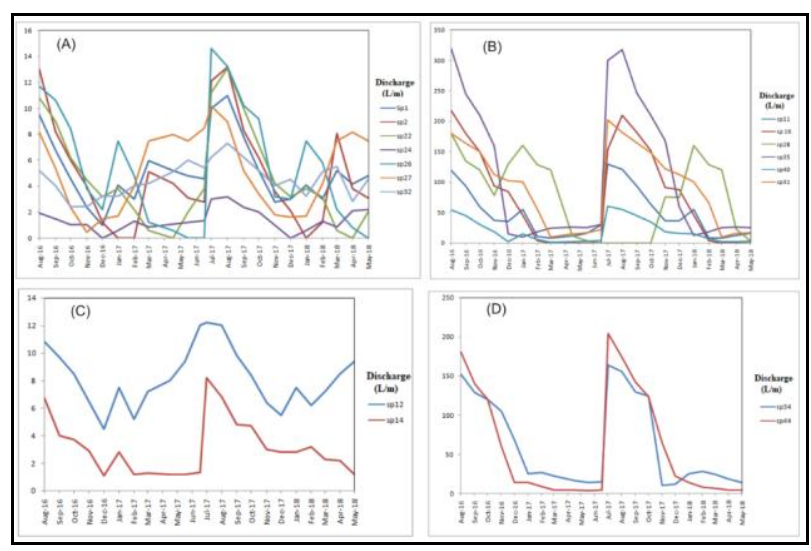

Figure 2(A -D). Discharge of different type of springs from August 2016 to May,2018

(A) Fracture joint-related type of springs, (B) Colluvial type of springs, (C) Contact springs (D) karst spring 
J. Mountain Res. P-ISSN: 0974-3030, E-ISSN: 2582-5011

Vol. 16(1), (2021), 103-109

DOI: https://doi.org/10.51220/jmr.v16il.9

Table 2: Hydro geological characteristics and discharge of the spring

\begin{tabular}{|c|c|c|c|c|c|c|}
\hline SPN & Location & $\begin{array}{l}\text { Type of } \\
\text { Springs }\end{array}$ & $\begin{array}{l}\text { Discharge } \\
\left(\mathbf{L m}^{-1}\right)\end{array}$ & $\begin{array}{l}\text { Average } \\
\text { Discharge } \\
\left(\mathbf{L m}^{-1}\right)\end{array}$ & $\begin{array}{l}\text { Temp } \\
\left({ }^{0} \mathrm{C}\right)\end{array}$ & Lithology \\
\hline SPN-1 & $2 \mathrm{~km}$ from Harsil & $\mathrm{F} / \mathrm{J}$ & $2.4-11$ & 5.2 & 12 & $\begin{array}{l}\text { Biotite Schist } \\
\text { (Gupta\& Dave,1982) }\end{array}$ \\
\hline SPN-2 & $3 \mathrm{~km}$ from Harsil & $\mathrm{F} / \mathrm{J}$ & $1.2-13.2$ & 5.15 & 14 & Biotite Schist \\
\hline SPN-3 & $1 \mathrm{~km}$ from Jhala & $\mathrm{Cl}$ sp. & $0.2-5.7$ & 1.9 & 12 & Biotite Schist \\
\hline SPN-4 & $1 \mathrm{~km}$ from Jashpur & $\mathrm{Cl} \mathrm{sp.}$ & $1.2-7.3$ & 4.22 & 15 & Migmatite \\
\hline SPN-5 & Sukki 1 & $\mathrm{Cl}$ sp. & $4.2-25$ & 10.22 & 15 & Garnetiferous mica schist \\
\hline SPN-6 & Sukki 2 & $\mathrm{Cl}$ sp. & $0.6-17.4$ & 6.1 & 16 & Garnetiferous mica schist \\
\hline SPN-7 & Sukki 3 & $\mathrm{Cl} \mathrm{sp.}$ & $1.5-44$ & 19.22 & 15 & Migmatites \\
\hline SPN-8 & Sukki 4 & $\mathrm{Cl}$ sp. & $4.0-20$ & 12.94 & 15 & Migmatites \\
\hline SPN-9 & Sukki 5 & $\mathrm{Cl}$ sp. & $4-5-56.2$ & 24.79 & 16 & Garnetiferous mica schist \\
\hline SPN-10 & Sukki 6 & $\mathrm{Cl} \mathrm{sp.}$ & $6.2-26.8$ & 12.33 & 17 & migmatites \\
\hline SPN-11 & Sukki 7 & $\mathrm{Cl} \mathrm{sp}$. & $8.5-130$ & 49.03 & 16 & Garnetiferous mica schist \\
\hline SPN-12 & Sukki 8 & Ctsp. & $5.2-12$ & 8.47 & 12 & Garnetiferous mica schist and migmatites \\
\hline SPN-13 & Lorinagpala & $\mathrm{Cl}$ sp. & $4-14.4$ & 7.63 & 15 & Migmatites \\
\hline SPN-14 & Gangnani & Ct sp. & $1.2-6.8$ & 3.25 & 13 & Calc Schist Marble and migmatites \\
\hline SPN-15 & Sunagarh 1 & $\mathrm{Cl} \mathrm{sp}$. & $2.1-28.5$ & 12.99 & 15 & Mica schist \\
\hline SPN-16 & Sunagarh 2 & $\mathrm{Cl} \mathrm{sp.}$ & $4.2-218$ & 77.22 & 14 & Augen gneiss \\
\hline SPN-17 & Sunagarh 3 & Cl sp. & $2.3-6.3$ & 3.82 & 15 & Migmatites \\
\hline SPN-18 & Bhukki1 & $\mathrm{Cl} \mathrm{sp.}$ & $2.2-8.6$ & 5.62 & 19 & Augen gneisses \\
\hline SPN-19 & Bhukki2 & $\mathrm{Cl} \mathrm{sp.}$ & 3- 18.2 & 8.46 & 19 & Migmatites,augen gneiss \\
\hline SPN-20 & Malla 1 & $\mathrm{Cl} \mathrm{sp}$. & $3.6-13$ & 4.58 & 21 & Migmatites \\
\hline SPN-21 & Malla 2 & $\mathrm{Cl} \mathrm{sp.}$ & $0.08-8.2$ & 3.76 & 20 & Migmatites \\
\hline SPN-22 & Malla 3 & F/J sp. & $2.0-13.1$ & 4.83 & 19 & Migmatites \\
\hline SPN-23 & Before Latta & $\mathrm{Cl} \mathrm{sp}$. & $8.0-18$ & 6.39 & 17 & Augen Gneiss \\
\hline SPN-24 & Sainj 1 (Ashram) & F/J sp. & $0.8-2.6$ & 1.46 & 18 & Metabasics \\
\hline SPN-25 & Sainj 2 & $\mathrm{Cl}$ sp. & $1.3-38.2$ & 12.18 & 15 & Quartzites \\
\hline SPN-26 & Bishanpur 1 & $\mathrm{~F} / \mathrm{J}$ sp. & $0.8-14.6$ & 5.63 & 16 & quartzites \\
\hline SPN-27 & Bishanpur 2 & F/J sp. & $1.8-10.2$ & 5.43 & 13 & Quartzites \\
\hline SPN-28 & $1 \mathrm{~km}$ from Naluna & $\mathrm{Cl}$ sp. & $4.2-180$ & 72.61 & 15 & Quartzites \\
\hline SPN-29 & Aungi & $\mathrm{Cl} \mathrm{sp.}$ & $0.9-7.2$ & 2.01 & 19 & Quartzite \\
\hline SPN-30 & Maneri & $\mathrm{Cl}$ sp. & $1.04-5$ & 0.71 & 20 & Quartzites \\
\hline SPN-31 & Heena 1 & $\mathrm{Cl}$ sp. & $10-180$ & 93.6 & 21 & Quartzite with limestone \\
\hline SPN-32 & Heena 2 & F/J sp. & $2.4-7.3$ & 1.2 & 18 & Quartzite \\
\hline SPN-33 & Natala 1 & $\mathrm{Cl} \mathrm{sp}$. & $1.8-17$ & 2.95 & 16 & Quartzite \\
\hline SPN-34 & Natala 2 & KSp. & $10.2-164$ & 63.43 & 17 & Limestone \\
\hline SPN-35 & Garampani & $\mathrm{Cl}$ sp. & $10-320$ & 118.07 & 18 & Quartzite \\
\hline SPN-36 & $\begin{array}{l}\text { Laksheshwar } \\
\text { (Ujeli) }\end{array}$ & $\mathrm{Cl}$ sp. & $3.2-12.2$ & 6.33 & 17 & Quartzite \\
\hline SPN-37 & Chungi Badethi & Cl sp. & $1.2-7$ & 1.5 & 17 & Quartzite \\
\hline SPN-38 & Tiloth 1 & Cl sp. & $1.8-5$ & 1.09 & 18 & Quartzite \\
\hline SPN-39 & Tiloth 2 & F/J sp. & $1.3-23.2$ & 7.99 & 18 & Quartzite with limestone \\
\hline SPN-40 & Mandon 1 & $\mathrm{Cl}$ sp. & $2-54.5$ & 21 & 20 & quartzite \\
\hline SPN-41 & Mandon 2 & $\mathrm{Cl} \mathrm{sp.}$ & $1.5-17$ & 4.24 & 19 & quartzite \\
\hline SPN-42 & Mandon 3 & $\mathrm{Cl}$ sp. & $0.8-11.3$ & 2.44 & 21 & quartzite \\
\hline SPN-43 & Mandon 4 & $\mathrm{Cl} \mathrm{sp.}$ & $1-5.2$ & 2.79 & 20 & Quartzite \\
\hline SPN-44 & Bonga 1 & Ksp. & $3.8-180$ & 62.37 & 21 & Limestone \\
\hline SPN-45 & Bonga2 & $\mathrm{F} / \mathrm{J}$ sp. & $\begin{array}{l}10.2- \\
355.5\end{array}$ & 115 & 22 & Limestone with quartzite \\
\hline
\end{tabular}


This alteration of recharge and discharge is the cause of seasonal, local, and short-term springs fluctuations. Balance precipitation and attendant recharge produce an uninterrupted water discharge in July/ August/ September, decreasing, causing the deficit, and then rising as the snow starts melting. Springs fed by shallow subsurface water emplaced above the water table are subject to the most significant fluctuations and may completely disappear at a particular time. Springs fed by groundwater have a steady supply, even though discharge varies seasonally. It is observed that the colluvial springs yield is higher in comparison to the fracture joint-related springs (Fig.2, A, B). The average discharge of the colluvial spring varies between $1.09 \mathrm{~L} / \mathrm{m}$ at Tiloth to $118.07 \mathrm{Lm}-1$ at Garampani, while for the fracture joint-related springs, average discharge varies between 1.46 Lm-1, at Sainj (Ashram) to $115.17 \mathrm{Lm}-1$ at Bonga. The highest discharging water springs in the study area are at Garampani (average 118.07 Lm-1), Bonga (average 115.17 Lm-1), Sukki (49.03 Lm1), Sunagarh (average 77.22 Lm-1), and Heena (average 93.69 Lm-1), while Hot spring located at Gangnani shows highest discharge rate $(24 \mathrm{~L} / \mathrm{m}$ to $98.2 \mathrm{~L} / \mathrm{m}$ ) with an average $52.39(\mathrm{Lm}-1)$. All the highest discharging standard water springs are associated with colluvial material, which suggested that the underlying aquifer system is porous and permeable, holding the right quantity of water. The water discharge rate varies from one spring to another depending on the local condition from where it is emanating.

Precipitation, spring discharge, and climate variability

The spring hydrographs are prepared to study the relationship between rainfall and discharge pattern (Fig.3, A to L). The discharge curves obtained for the study area's springs show a periodic rhythm with the rainfall pattern. The area received the highest rainfall during the monsoon period; it also raises the area's water level by the high amount of water percolation, thus the discharge of spring's increases. Generally, springs hydrographs are following a rainfall pattern. Thus, they show a direct relationship with precipitation, and most of the aquifers are recharged by rainwater. The hydrograph obtained for the Harsil spring (Fig.3, A) shows a fair discharge during the pre-monsoon months.

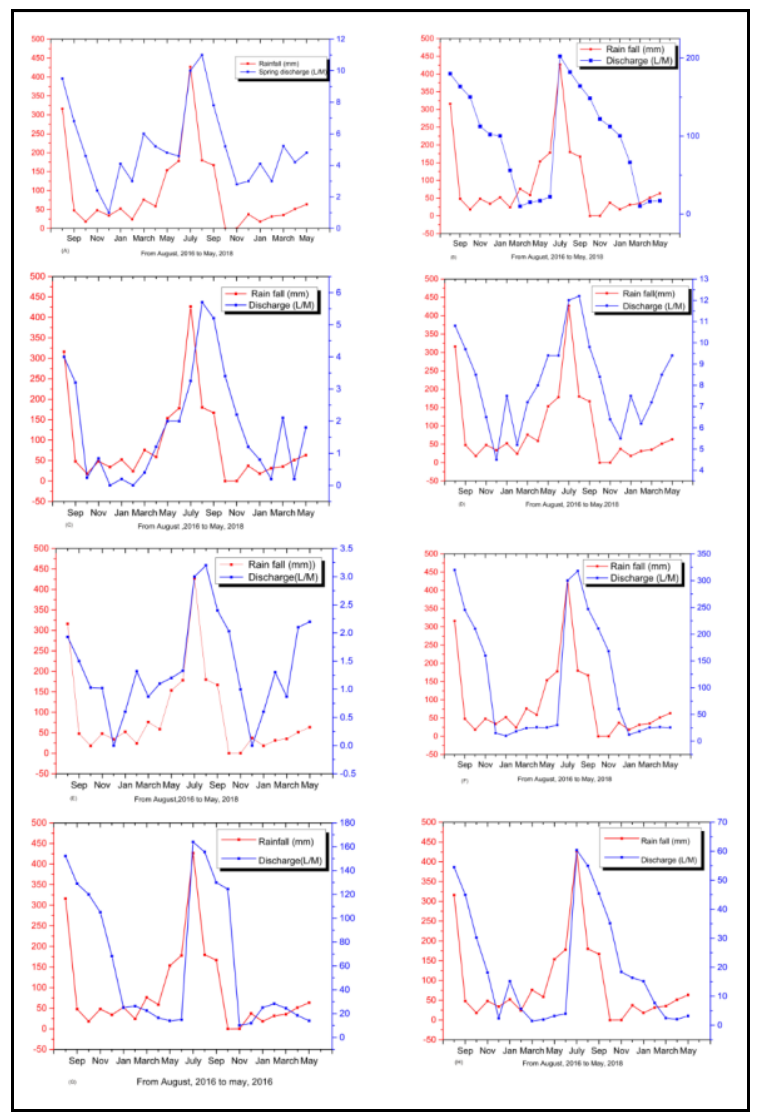

Figure 3(A, H): Hydrograph between rainfall and discharge of the springs (A) Harsil, (B) Heena, (C) Jashpur, (D) Sukki, (E) Sainj(Ashram), (F) Garampani(G) Netala, (H) Mandon

The area receives heavy snowfall between November and January, resulting in decreases in spring discharge; thus, the low percolation occurs due to freezing of pore spaces. During the premonsoon period, snow starts thawing, and thus there is a gradual increase in spring discharge. The hydrograph of colluvial related springs of Heena, Garampani, Sukki, Mandon, Jashpur, Netala, etc., suggested that the associated aquifer system is porous permeable, holding a good quantity of water. 


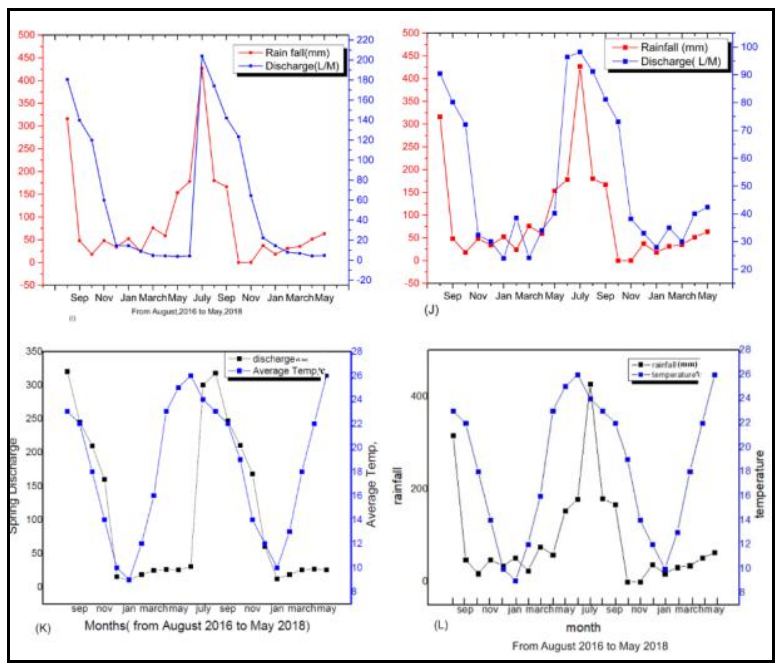

Figure 3 (I, L): Hydrograph between rainfall and discharge of the springs (I) Bonga, (J) Hot sp. Gangnani, (K)graph between discharge and temperature (L), Graph between rainfall and temperature

During the post-monsoon season, colluvial springs maintain their discharge despite low rainfall, while during the pre-monsoon season, a decrease in discharge occurs until the monsoon season arrives. Few colluvial springs (Chungi Badethi and Maneri) appear only in the monsoon season except (Sunagarh, Malla, Naluna, Heena 2, Tiloth, and Mandon3) all springs are perennial. The discharge curve obtained for karst spring at Bonga shows a rhythmic pattern with rainfall. High discharge occurs during the monsoon period, while it is decreased during the winter season with decreasing rainfall. Hydrograph of hot spring located at Gangnani (Fig.3. J) suggested the direct relationship of spring discharge and rainfall was evident. The annual shifts in the peak discharge were mainly due to rainfall. In the proposed area, the spring discharge strongly correlated with the melting of snow/glaciers (fig.3.K) showing the variability of the spring discharge due to changes in the monthly temperature. Rise in temperature during (February-July), an increase in spring discharge is witnessed. However, in the following months (August-January), discharge of the spring decreases with the temperature. Low discharge witnessed due to the moderate rainfall with moderate temperature, while during (May to June) rise in temperature also induced the rainfall in the area after that it decreased with temperature to low percolation capacities and low runoff. Lowest melting of snow/ glaciers due to low temperature in (December to January). Elevated temperature induces snow/ice melting during (May-July) and serves as an essential groundwater recharge component. Comparison of rainfall and average temperature data (Fig.3.L) shows that during premonsoon season study area.

\section{Conclusion}

Springs are an essential water resource in the Himalayan region, the maximum population in the mountain region dependent on spring water for drinking and household purpose. Based on lithological formations related to the opening of springs are classified into fracture joint, colluvial, contact springs, and karst springs. The area constitutes high-grade metamorphic rocks of lesser and central crystallines of Garhwal, Himalaya, providing an aquifer system in the region. The high porosity and high permeability of alluvium deposited by the Bhagirathi river are suitable for groundwater development in the study area. Fracture joint-related springs of the Uttarkashi region show less impact of rainfall and perennial. Colluvial type of springs shows excellent water yield during the monsoon period, after rain, discharge started diminishing, shows its direct relationship with rainfall pattern. Two springs, such as Chungi Badethi and Maneri, appear only in the monsoon season during heavy rain. Contact springs are perennial in nature, fractures, and joints in the hard rocks providing a sufficient amount of water to the aquifers. In karst aquifer system, rainfall percolates slowly into the aquifer, and rapid flow through the outlet is observed (Bonga). The highest discharge coincided with the highest rainfall during the monsoon season. During nonrainy days in post monsoon season, spring discharge starts decreasing. After that, it starts increasing in the pre-monsoon season. The discharge of spring has a direct relationship with temperature and rainfall. As the temperature rises during themonsoon season, the study area witnessed heavy rainfall. Thus it induced the springs' discharge (fig.3.K, L), 
while a decrease in rainfall during post monsoon is associated with lower temperature and discharge. The study highlights the role of lithology, land use, slope, precipitation, temperature, snowmelt, and anthropogenic activities in the study area as a controlling factor on the study area's hydrogeological condition.

\section{References}

Agarwal A, Bhatnagar NK, Nema RK, Agarwal NK, (2012). Rainfall dependence of springs in the Midwestern Himalayan hills of Uttarakhand. Mou. Re. Dev., 32(4): 446-455.

Ashoka A, Gleeson T, Wada Y, Mishra V, (2017). Study on Relative contribution of monsoon precipitation and pumping to changes in groundwater storage in India. Nat. Geosci. 10(2):109

Bartarya SK, (1995). Hydrogeology and water resources of intermountain, Doon valley. J Him Geol., 6(2), 17-28.

Bisht NS, Srivastava AC, (1995). Sustainable Management and Conservation of Drinking Water Sources in Himalaya. Indian For, 7 , 608-612.

Panwar S, (2020). Vulnerability of Himalayan springs to climate change and anthropogenic impact: a review. J Mou. Sci., 17(1).

Negi GCS, Joshi V. (2004). Rainfall and Spring Discharge Patterns in two Small Drainage Catchments in the Western Himalayan Mountains, India. The Envir., 24, 19-28.

Negi GCS Joshi V. (1996). Geohydrology of springs in a mountain watershed: The need for problem solving research. Curr. Sci, 1996, 71(10), 772-776.

Jeelani G. (2008) Aquifer response to regional climate variability in a part of Kashmir Himalaya in India. Hydr J., 16(8): 16251633.

Jeelani G, Shah RA, Fryar AE, Deshpandey, Rajendrakumar D, Mukhrjee A, Perrin J, (2018). Hydrological processes in glacierized high-altitude basins of the western Himalayas. Hydr J., 26(2): 615-628. (https://doi.org/10.1007/s10040-017-1666-1)
Valdiya KS, Bartarya SK (1991). Hydrogeological studies of springs in the catchment of the Gaula river, Kumaun Lesser Himalaya, India. Mou. Res. Dev., 11(3): 239-258. (https://doi.org/10.2307/3673618)

NITI Aayog, August (2018). Report of Working Group I Inventory and Revival of Springs in the Himalayas for Water Security.

Gupta SK, Dave VKS (1982) Petrology and metamorphism of the upper Bhagirathi valley Central crystallines, District Uttarkashi U.P. Himalaya publ. in Him, Geol, volume 9 part II 512-528.

Tiwari P (2008) Land use changes in Himalaya and their impacts on environment, society and economy: A study of the Lake region in Kumaon Himalaya, India. Adv. Atmos Sci., 25(6): 1029-1042.

Rai RN, Singh KA, Solanki RC,(1998). A Case Study of Water Flows of Some Hill Springs of Sikkim. Indian J. Soil Cons. 16(1), 52-56.

Semwal R, Nautiyal S, Sen KK, Rana UD, Maikhuri RK, Rao KS, Saxena KG (2004) Patterns and ecological implications of agricultural land-use changes: a case study from central Himalaya, India. Agri. Ecos. Env., 102(1): 81-92. (03)00228-7

Gupta SK, Deshpande RD (2004) Water for India in 2050: first order assessment of available options. Curr. Sci., 86:1216-1224

Sahin V, Hall MJ, (1996). The Effects of afforestation and Defforestation on water yields, J. hydrol.178, 293-309.

Yang GS, (1999). Global changes and the study to natural disaster trend of China. Geosci. Dev 14(1):1-83

Hasnain SI, (1999). Runoff characteristics of a glacierized catchment, Garhwal Himalaya, India. Hydrol Sci J 44(6):847-854

Gergan JT, Dobhal DP, Kaushik R (1999). Ground penetrating radar ice thickness measurements of Dokriani Bamak Glacier, Garhwal Himalayas. Curr Sci.,

$$
\text { ******* }
$$

